\title{
SUSTAINABLE RURAL TOURISM DEVELOPMENT IN CANTON X OF BOSNIAAND HERZEGOVINA
}

\author{
Suzana Đorđević - Milošević*, \\ Boris Vakanjac, \\ Mesud Adžemović
}

Singidunum University, Belgrade, Serbia

\begin{abstract}
:
Despite its favorable position in the Adriatic Sea hinterland and its good connection with the emitting markets, Canton $\mathrm{X}$ is still underutilized tourist destination - "terra incognita" for all but skiers and passerby travelers heading toward Adriatic coast. In similar territories, holding precious agriculture traditions, valuable products, and rich and diverse cultural and natural heritage, rural tourism was already successfully introduced. In this respect, the hypothesis that rural tourism could become the backbone of the future Canton X rural economy seems easy to prove. Yet, considering existing tourist attractors and factors, as much as services provided, rural tourism development seems not to be as simple task as presumed. The line of weaknesses and shortcomings are detected in its value chain requiring numerous interventions, as much as integrated, area-based developments approach. The fragile Dinaric natural environment and complex socio-economic features of the region appear a challenge, rather than a simple opportunity. Besides discovering frames, potentials as much as concerns related to rural tourism development, this paper is also attempting to model rural tourism for versatile use of available resources which can contribute to sustainable diversification of Canton X rural economy while keeping the environment safe and social fabric inherently preserved.
\end{abstract}

\section{Keywords:}

sustainable tourism, area-based development, tourism in fragile environments, Dinaric Arch.

\section{INTRODUCTION}

Canton $\mathrm{X}$ is one of the most attractive areas in Balkans. If the Organization for Economic Co-operation and Development criteria are applied, Canton X is entirely rural. $68.33 \%$ of the population lives in rural areas and the rest in small urban centers. It is an authentic and tremendously attractive Balkan rural area with the immense heritage and valuable living rural traditions. In similar rural environments worldwide, rural tourism is introduced as a valuable economic activity, being capable of mobilising human and natural resources to improve livelihoods of local rural communities. Although mainly well accessible, Canton $\mathrm{X}$ is left behind, widely known for only few of its products skiing on Kupres, Livno cheese and Glamoč potato, while view on its immense cultural and natural heritage remain blurred.
Correspondence:

Suzana Đorđević - Milošević

e-mail:

sdjordjevicmilosevic@singidunum.ac.rs 
Apart from the urban centers, cantonal economy is highly dependent of primary sector, with the considerable contribution of subsistence farming. Population of Canton X intensively out-migrates, due to the extreme dissatisfaction with the quality of life and unemployment in rural areas. Therefore, rural development has been defined as one of the main economic, social, and environmental challenge by Canton X Government; local economy should be diversified, while primary and further secondary industries more efficient and better valorized. The fundamental hypothesis is that the sustainable rural economy diversification based on numerous underutilized resources supposed to create new employment opportunities and consequently improve livelihoods. Tourism has been recognized as the key sector, which can drive it through facilitating establishment of firm synergies between various economic sectors. Rural tourism is observed in Canton $\mathrm{X}$ as a potent economic activity capable to utilize multifunctional features of agriculture and absorb local products. To confirm this hypothesis, cantonal resources should be thoroughly explored, risks and constraint understood, and possible rural tourism development scenarios created and rated. This research was preceding work on a feasibility study for rural tourism development in Canton X.

\section{LITERATURE REVIEW}

According to the Voluntary National Reviews, tourism appears to be largely recognized as a high-impact sector with potential to advance all Sustainable Development Goals (SDG) (United Nations Development Programme, 2018). From the beginning of this century, numerous authors have attempted to prove that rural tourism is one of the most important factors for securing the sustainable rural development (Stagl, 2006, Udovč and Perpar, 2007, Nurkovic and Dzeko 2014). Of course, the capacity of rural tourism to contribute to the resolution of problems in rural areas was evolving, depending on how a number of critical issues was resolved, its organization improved, participants expanded and support policy built as predicted by Keane (2000). Tourism, as much as rural tourism as its segment, is after all lessons learned seen as an opportunity to advance with the SDG, but also the one who can challenge some. Challenges enlisted were mostly related to SDGs 12, 14 and 11 with the emphasis on „Responsible Consumption and Production“ (United Nations Development Programme, 2018). Heritage-based tourism such as rural tourism, depend in large extent of the cultural and natural heritage sustainable use and might have complex financial and cultural consequences (Ničić, 2015).Therefore, selection of resources and modes of their exploitation should be part of business environment analysis as much as the risk assessment should precede design of risk mitigation measures. In that case creation of different tourism development scenarios will have much more chance for success. This research is exploring potentials and designing rural tourism which can hold SGD achievement in an extremely socially and environmentally fragile rural region in West Balkans - often called simply "Livno area" although wider - the territory of Canton X of Bosnia and Herzegovina.

\section{METHODOLOGY}

The overall goal of this research is to identify the most feasible rural tourism features which can contribute to socially, economically, and environmentally sustainable rural development in Canton X. The study is targeting part of the territory of Federation of Bosnia and Herzegovina situated in its west-south-west part, along the border with Republic of Croatia. It is predominantly mountain region situated in Dinaric Arch, which belong to six municipalities, namely: Bosansko Grahovo Drvar, Glamoč, Kupres, Livno and Tomislavgrad (former Duvno).

The introductory desk work was completed to explore the policy and legal frames for the rural tourism development in Canton X. The following survey was conducted with participation of 30 local food and drinks producers (farmers and entrepreneurs), to explore their attitudes regarding the value of the environment in which they live, the resources they have, as well as comparative advantages in relation to other areas in the function of developing rural/agro-tourism products and its placing on the market. The survey contained 16 questions, open and closed. Identification and estimation of tourism assets was conducted in a participatory way with the group of regional stakeholders, members of the Cantonal rural development strategy development group, using simplified Factors attractors and services analysis (FAS) methodology (Fayos-Solà at al, 2014). 
Data were analyzed in stakeholders groups to provide estimation of the suitability of the position, traffic and infrastructure, relations \& networking with other commercial \& public entities, tourism marketing system, organization and management, assessment of the support to tourism development and position of tourist products in Canton X. An extensive survey of Canton X territory was conducted on the field for getting wide picture of the space and individual overview of the potentials for rural tourism development and complemented with the desk research. Findings from this survey were summarized and exposed to Strengths/Weaknesses/ Opportunities/Threats (SWOT) analysis for estimating conditions for rural tourism development. Data were analyzed in groups to provide estimation of the suitability of the position, traffic and infrastructure, relations \& networking with other commercial \& public entities, tourism marketing system, organization and management, assessment of the support to tourism development and position of tourist products in Canton X. Selected development models were exposed also to the risk assessment.

\section{RESULTS}

The Law on Tourist Activities (Federation of Bosnia and Herzegovina, 2009a) and the Law on Catering Services (Federation of Bosnia and Herzegovina, 2009b) exist in Bosnia and Herzegovina Federation, but definition "rural tourism" is not mentioned within these regulations. The tourist sector of Federation of Bosnia and Herzegovina legislation is using descriptive for touristic activities carried in rural areas and villages (Sivrić, 2020). Bosnia and Herzegovina Rural Development Strategic Plan 2018-2021 Ministry of Foreign Trade and Economic Relations, 2018) is enlisting rural tourism as the potential activity for rural development, defining rich natural and cultural heritage of the country as capital providing possibilities for diversifying rural economy. The Law on Agriculture, Food and Rural Development of Bosnia and Herzegovina (Bosnia and Herzegovina, 2008) have included measures supporting diversification of economic activities in rural areas and measures targeting improvement of the quality of life in rural areas: support for introducing supplementary activities and, so called, non-agricultural services, measures to improve rural areas and preserve the natural and cultural heritage and other associated measures. Rural tourism is recognized as feasible also in Tourism Strategy for Federation of Bosnia and Herzegovina 2011-2021 (Federation of Bosnia and Herzegovina, 2011).

Canton X Development Strategy for the period 2016-2020 (Vlada Herceg-Bosanske Županije, 2016) emphasizes that the Canton space is special, preserved, and unique which provide opportunities for the development of various forms of tourism and therefore declares as one of primary goals sustainable development of tourism as much as the necessity of preserving the integrity of resources to create a competitive tourism product. The development model of Canton X presented in the Development Strategy of Canton X (Vlada Herceg-Bosanske Županije 2016) is based on the principles of sustainable development, given the need for simultaneous valorization, as well as the preservation of natural resources and cultural and historical heritage. Given the commitment to sustainable development in the function of improving the local population, the development of winter tourism, ecotourism, adventure tourism, ethno-tourism, cultural tourism, or the development of experiences that will combine the elements (parts) of the mentioned forms of tourism are acceptable for this area. Strategy for Agriculture and Rural Development in Canton X, 2018-2024 (Vlada Herceg-Bosanske Županije, 2018) provide vision and objectives for agricultural and rural development. Investment support to the development of the tourism sector is seen as a relevant instrument intended for creating new employment opportunities and income generation in rural areas of Canton X.

\section{Regional potentials for rural tourism through small producers of local food and drinks introspective}

Farmers and entrepreneurs producing local food and drinks have ranked the quality of water, air and agricultural products, as the main assets for tourism. 28 respondents from 30 are most proud of their surroundings and / or villages, natural beauty of the countryside, landscapes, healthy environment, winter lake tourism, and mountains, but also hospitality and hard-working population, and preservation of tradition in culture. The perception of the respondents ( 19 out of 30 ) is that it is an abundance of nutritious wild and medicinal herbs, the production of local brandy and quality honey, authentic dairy products for this area (cheeses) is as much attractive potential for tourism development as the regional history and good conditions for winter activities. 
Basic resources / events / products by which the area is famous are rated on the scale from the grade 1 - not relevant to the 5 - most significant. The importance of natural and cultural resources, the quality of the environment, the specificity of breeds of animals, conditions for tourism, hospitality, and gastronomic offer, got the highest ranks. Highest figures respondents have used to rank the quality of water, air and agricultural products, while the lowest are granted to events. 25 of 30 respondents think that there is a possibility of better linking of tourism and gastronomy, and that this relationship will attract more tourists. Better legal regulation is required to make this possibility achievable. 19 respondents are interested in tourism as an additional activity, and up to now, only one agricultural holding and cooperative have been involved with the tourist activities, through participation in short food supply chains. Respondents are rarely familiar with the production of products with medicinal properties or other positive effects (11 respondents did not answer, while others listed honey, tea, cornelian cherry, goat milk and cheese).

When asked "What are the typical services / tourist activities of the region", most respondents listed winter sports, hiking, hunting and fishing, one respondent said gastronomic services, while other respondents listed attractive for nature areas or cultural and historical monuments. Wild fruits harvesting, cutting wood for heating and technical use, hunting and fishing and local events were identified by respondents are highly important economic activities based on local ecosystems services. The role of hunting is estimated as modest and insufficient. The hunting for wild boar, deer, bear, and trout is mentioned as present, but very few respondents mentioned the other game species.

Products that, in the opinion of the respondents, have the greatest potential for placement through the tourist offer are cornelian cherry products, honey, meat products, Livno cheese, Livno beer and home-made preserves. Several respondents commented that these products only have a perspective if they get legal protection. Such law is needed as soon as possible. Only few respondents think that traditional local products/services can be profitable, but only if subsidized. The majority think that Canton X products are underestimated on the market (too cheap considering their quality). Responders think that their products are better than similar from other regions because they are produced in a traditional way and related to biodiverse biological resources such as pastures for instance. They believe that promotion of traditional regional food, through rural tourism can help them sustainable develop regional rural economy, which is a positive sign that they can easily fit with the global strategies for diversification of rural economies (Đorđević-Milošević, 2020), as much as the philosophy of shortening food supply chains for promoting small farms. The positive attitude of the kind is opening widely entrance for the promotion of the alternative livelihoods (Đorđević-Milošević and Milovanović, 2014 and 2020) in this fragile natural environment. Sustainable rural development models which are developed in last decade (Food and Agriculture Organization of the United Nations, 2008, Đorđević-Milošević and Milovanović, 2012) will correspond to both natural environment and local communities in Canton X.

\section{Potentials for rural tourism development as seen by regional rural development stakeholder group}

Deepening of the knowledge about the potent solutions continued with the identification and estimation of tourism assets with rural development stakeholders group. Relevant tourism factors, which have not yet been developed, were rated with an average grade of 2.87. The lowest rated were capital factors (1.83), due to the limited access to financial support in Canton X. The human capital allocation factors were rated with 1.91, due to the emigration of professional labor; this factor should be considered as a major threat for the further development of rural tourism in Canton X. The overall average score of natural factors in Canton X, according to the analysis of the stakeholder group is 4.88 . Out of 17 identified natural factors, a group of stakeholders had assessed the biodiversity and beauty of natural factors, as well as potentials of micro-location, that have the potential to attract the tourists. Canton $\mathrm{X}$ is an area rich in rivers and lakes, that had been identified by the group of stakeholders as the main factors for tourism development were: the Unac River, the Prekaj Lake, the Bastaško Lake with spring and Bastašica stream, Hrast and Busija Lakes, the Ždralovac Lake, the Kukavica and Buško Lake, and artificial Preodac and Borovačko Lake, as well as a number of attractive mountain destinations and caves (more identified natural factors with a high potential for attracting tourists were also mentioned.

As the most relevant social/human factor, besides the enthusiasm in local community, whose significance was emphasized by stakeholders from Drvar, was a lack of professional labor. 
This is the result of the long history of outmigration of professional personnel (longer than the postwar period, since outmigration was intensive already from $60 \mathrm{~s}$ of the $20^{\text {th }}$ century), which already undermined local economy. The final assessment of human factors and the level of development according to the analysis of the stakeholder group is 1.91 out of 5. Canton X rural areas according to the analysis of the stakeholder group is an area with very limited financial capital and the availability of favorable loans. The average mark for the capital factors was low - 1.83 out of 5. Internal investment potential insufficient while rural areas of Canton $\mathrm{X}$ are not attractive enough for external investors. Small number of investments in rural family households derive mostly from local people working abroad.

Traffic Infrastructure factor: Road infrastructure was rated as 3.2 by the group of stakeholders of Canton X, however, this average does not reflect reality prospective since the stakeholders of Glamoč municipality point out that regional road network in their municipality continuously degrade, while the municipality of Grahovo did not evaluate the road infrastructure at all, having major gaps spread through the territory with no chance to be filled. The air infrastructure, on the other hand, is rated at 1.67, although Livno is on its way to upgrade their sports airport to the regional one.

Attractors The classification of attractors is based on the natural, cultural and elements of activity centers. This shapes relevant tourist attractions in Canton X. Through the list and analysis of tourist attractions performed by the group of stakeholders, the final score is 3.77 which shows great endogenous impulse for the development of the tourism sector. Group of stakeholders have identified 11 major natural attractors and rated it as an average of 3.55, reflecting a high degree of their value in attracting tourists, while the average rating of potential for the future is 4.81 , indicating the great potential for their increase of the attractiveness in the future. The average assessment of the current situation encompassed visitor ratings, beauty and accessibility for tourism; while the average assessment of the potential for the future included: the possibility of improvement, the increase of visitors and the improvement of accessibility for the future.

The group of stakeholders rated cultural attractions as 3.9, indicating a high level of value of cultural attractions in Canton $\mathrm{X}$ as a tourist resource. This average assessment of the current situation reflects a high level of value in the offer of existing tourism products related to cultural attractions, while the average assessment of the potential for the future, which is 4.40 , indicates the existence of the solid ground for tourism development. The average assessment of the current situation encompassed visitor ratings, beauty and accessibility for tourism; while the average assessment of the potential for the future included: the possibility of improvement, the increase in visitors and the improvement of accessibility for the future.

Additional services support refers to the areas of the tourism industry, which support tourism activities in given destinations. The average rating of auxiliary support services in Canton $\mathrm{X}$ according to the analysis of the stakeholder group is 2. A group of stakeholders assessed the accommodation capacities and restaurants in Canton $\mathrm{X}$ with an average score of 3.23, while the average assessment of the potential for the future 4.9. The average assessment of the current situation included category ratings and capacity / availability.

Although the Split, Mostar and Zadar Airport are relatively close, the group of stakeholders, probably due to the lack of adequate terrestrial transport links, does not recognize air transport as a significant support to tourist destinations on their territory (score 2, based on only one rating from Livno, which have rated connection with the Split airport as satisfactory). Most stakeholders have scored the municipality's connection by bus very low. According to the stakeholders, only Glamoč and Livno have better bus connections. The average score for inland transport is 2.13. The Municipality of Kupres points out that the lack of a bus station represents a serious problem. Stakeholders have not identified other internal transport factors (train, taxi) as significant support of tourist destinations in their area. In Kupres and Livno a bicycle rental service is available - rent a bike, which was assessed by stakeholders with a score of 2.25. Renting horse for riding tourists is available in Glamoč, Kupres and Livno and is has been rated as 2.33 .

\section{Estimating conditions for rural tourism development (an expert birds-eye view)}

Strategic potentials. SWOT analysis has shown a relatively restricted set of strengths, weaknesses, opportunities, and threats. Nevertheless, on this basis, a wide range of strategic actions might be created to lead to the construction of high-quality tourism products. They will give a completely new character to this area, whose 
primary enormous significance stems from the existing natural and cultural heritage, but also human resources existing in civil and private sector. Here, we primarily took into consideration strategic competitive advantages on which Canton X can build its rural tourism offer in the near future. The potentials which can provide strategic advantages for establishing unique offer and products can be defined as follows:

- Positive attitude of the population of Canton X towards tourism, openness, traditional hospitality, and a strong emotional experience that the guest experiences during his stay in Canton X.

- Local schools educating adequate profiles and presence of certain number of professionals educated abroad, as much as enthusiastic and knowledgeable CSO sector, could give a strong boost to tourism development if mobilized within their competences.

- The geostrategic position of Canton X is on the traditional caravan route of salt between the Pannonian lowland and the Adriatic Sea, today's transversal linking European Corridor 10 and the Mediterranean Highway. Canton X represents the still undiscovered tourist destination of Southeast Europe, which in the community with the wider Dinaric Balkan belt represents a perspective area for the development of sustainable forms of tourism, among which rural tourism certainly occupies a prominent place.

- The great unused potential of Karst region, rich in waters, mountains, and the underground, is priceless for rural tourism development with its preserved geo and biodiversity, as a unique set of attractions in this part of Europe.

- Ancestral heritage of monuments of different epochs and cultures, intangible cultural heritage, with significant cultural, spiritual and religious centers, cultural tradition and attractive local products agricultural, artisan food and wildlife, as the source for economic benefits, as much as an inspiration of the multi-ethnic community.

- Local events that reveal the characteristics of the local community and its eternal way of combating and adapting to harsh climatic conditions and wild nature, make the area unique and more interesting than many others. This, along with the additional elements of diverse cultural and historical influences from Illyric times and Rome, through the Ottoman to the Austro-Hungarian Empire, and the period of the rule of communist philosophy, leads to the present and the efforts to modernize and enrich the space, while preserving its wild beauty for the future.

The main strategic shortcomings that Canton X should solve to succeed in the tourism market are:

- The international market still has no awareness of Canton $\mathrm{X}$ as a tourist destination. The reason is mostly the fact that Canton X, apart from ski and horse tourism in Kupres, never worked on the commercialization of other tourist products and built a tourist offer on available resources using the experience from the world and the surroundings. There is no system of managing a tourist destination that could, along with adequate promotion budgets, raise the interest of tourists for these areas. Consequently, the Canton $\mathrm{X}$ is known as a transitory territory which should be passed to reach ski-centres of Kupres or the Adriatic coast, while the north-east part of the Canton X (except Drvar) remained unknown to tourists.

- Natural and cultural heritage is well-known but hardly truly conserved. Majority of it is exposed to degradation and devastation. For instance, due to the war destruction of cave equipment, facilitating visits of laics, from the tourist map disappeared even such attraction as it is Ledenica cave - one of the most beautiful, if not the most beautiful cave in the former Yugoslavia. Natural and cultural heritage will benefit in great extent if finally used for tourism, since it will bring money for their maintenance. If not used, degradation might continue.

- Lack of generally accepted cantonal vision of tourism, the lack of local (municipal) visions, and the lack of structuring tourism of the Canton $\mathrm{X}$ on the basis of dominant experience or cluster principles, except in the Kupres municipality (Federalno ministarstvo okoliša i turizma , 2009; Lugonja, 2013), completely marginalized the importance of tourism as a potent economic activity for sustainable diversification. Canton X local rural economies can benefit a lot of rural tourism as a tool to better valorize the available resources and the adding value instrument for local food and agriculture industry.

- Due to insufficient cooperation and coordination between different state institutions and relevant stakeholders in tourism of Canton X, established spatial-urban regulation of most current and potential tourist 
destinations and centers is still insufficiently articulated. Disappearance of original architecture and disturbance of landscape's diversity due to the suspension of traditional farm practices, environmental incidents (illegal dumps, destruction of wetland habitats, forest fires etc.) attractiveness of the space is continuously decreasing, undermining tourism development.

- Insufficient awareness and/or understanding of the importance of the system of tourist experiences and the establishment of a comprehensive short value chain in preventing development of cantonal tourism products.

- Limited access to Canton X, or some of its tourist attractions, due to the lack of modern highways and general neglecting of local roads and communal infrastructure is slowing down economic development in general.

- Lack of internationally qualified hotel and tourism managers, staff with new tourism occupations (animation, entertainment, events management, theme parks coaches, interpreters centers, etc.), as well as limited employment opportunities for local tourist, gastronomy, and food production scholars.

- Strong outmigration and intensive depopulation of Canton X.

Considering both the strategic potentials and the main shortcomings identified, Canton X can devote itself to build rural tourism, offer diverse tourism products to the immediate surroundings (Balkan market) and European markets. Its tourism offer should combine attractive natural, historical, and social elements that the Canton is rich in. There are potentials for networking of all relevant sectors and stakeholders, to give a boost to rural tourism development. The upgrading of the roads, tourist, and communal infrastructure, which will enable local space to serve increased number of people visiting this area is, however, urgently needed. This is important to emphasize since more people moving into the region will make more crowd on roads and bring additional problems with environmental pollution, primarily due to the already insufficient communal infrastructure. Investments are primarily needed in construction of sewage systems and waste management. It is also necessary to eliminate risks for tourists that intend to come to the region, primarily by introducing final solution for removing the mines, as well as mitigating possible health risks and risks of injuries specific for the karst area through further strengthening of emergency and rescue services. Finally, Canton X need to safeguard its natural and cultural heritage (by all means), valorizing it through tourism which should be ultimately environmentally sound and sustainable in a long run.

\section{Proposed (feasible) rural tourism activities in Canton X}

The baseline analysis of the location, its natural resources, economy, and culture presented in FAS analysis and research with farmers and food producers are giving the solid basis for identifying main tourist assets which should be the fundament for designing rural tourism products. The logic behind is that rural accommodation as basic tourism products must be combined with activities in rural environment. Guests need to feel rural life and it is the main feature of the rural tourism, but this might not be enough, so all other kinds of activities using rural resources are welcome. Below are the most relevant tourist assets of the kind enlisted:

1. Biosphere experiences of Dinaric mountain arch - Sports, recreation \& adventure

2. Geodiversity of Karst - Scientific and speleological tourism

3. Sources, rivers and lakes - Fishing and recreation (Vacation areas - excursions and recreational tourism)

4. Protected natural values - Tourism of nature protected areas

5. Rare and attractive animals - Ecotourism

6. Agro-biodiversity for food and agriculture - Rural Well-Being \& Agro-Tourism

7. Local gastronomy - Agri-tourism, Gastro tourism, Edutainment

8. Rural Architecture - Agro-tourism and Rural wellbeing

9. The Monumental Heritage, cult personalities and celebrities - Cultural tourism

10. Local traditions - Event tourism

11. Spirituality, Religion and Lifestyles - Religious, Youth and Family tourism 
The most prospective and feasible model for rural tourism development in Canton $\mathrm{X}$ is based on integration with the nature and eco-tourism, including hunting tourism, adventure tourism, pilgrimage, or religions tourism. Therefore, strategic tourism positioning of Canton X should occur around the following destination types:

Canton X - The top adventure site in a natural environment (the adventure as a light motive)

Canton X - The top rural wellbeing - agro-tourism destinations (hedonism as a light motive)

Canton X - The top destinations for sport and recreation (activity as a light motive)

Canton X - The nation's cradle and the center of spirituality (the emotion of belonging as a light motive)

The most obvious market segments identified were those of: backpackers, guest from the seaside, tourist on a short vacation, families with small children, nostalgic city resident and expatriates, emigrants descendant, war veterans, employee under stress, recreation aspirant, retiree, locals celebrating anniversaries and friends picnicking, local hotels business guests, rural wellbeing \& gastro-tourists, hunters and fisherman, the cycle tourists and bikers, mountaineers, speleologists and climbers, air-gliders, parachuters and other adrenaline addicts in the air, sport clubs trainees, artists, pilgrims, a horse devotees, photo enthusiasts \& professional photographers, explorers, bird-watchers and wildlife observers, people with special needs and excursionist.

\section{Environmental impact and risks of the proposed model}

Canton X is extremely environmentally fragile due to its karst character (Kodžo et al 2015). To develop an area of such a complicity, economic activities should be extremely carefully shaped and conducted. In the case of rural tourism and its possible environmental impact it is of essential significance to understand regional karst hydrology. Rural tourism impact on environment depend a lot of its intensity and level of provided infrastructure. Detailed risk assessment was conducted and risks mittigation hints were provided for the activities in the underground and on the land surface (incl. caving, tracking, horseback and bicycle riding, hunting and wildlife watching etc.) and food supply. Other hazards with possible impact on rural tourism are also revealed, such as safety in traffic, undiscovered land mines from the war period 1992-1995 and natural risks such as severe weather and wild predators. The rural tourism impact on environment depends a lot on its intensity and level of provided communal infrastructure, but it is basically related to few types of influence which do not differ a lot from those which are widespread in Federation of Bosnia and Herzegovina (United Nations Economic Commission for Europe, 2018):

1. Waters and soil pollution from sewage water and waste due to the logging and activities in nature

2. Air pollution with gases, aerosols, and noise due to the utilization of motor vehicles

3. Water pollution due to bringing chemicals into water while swimming

4. Destruction of wildlife and their habitats

5. Disturbance of wildlife in their habitats (moving or shooting)

Activities in the underground Geotourism is one among many types of ecotourism or nature tourism activities which is matching with rural tourism in karst areas such as Canton X. Cave tourism within geotourism has gained popularity bringing additional risks for the environment of Canton X. Caves as an attraction for rural tourist destinations supports rural tourism development in the countryside of many developing countries, so this challenge is acceptable for Canton X too. However, specific hazards and impacts may affect endemic geo-morphological, hydrological, and ecological peculiarities of extremely fragile karst and caves environments and require specific risks mitigation. It starts with the selection of activities to match with rural tourism. Types of activities to be considered are mainly low intensity activities and presence of small groups in caves, which is much more suitable than presence of mass tourism, which is often in the most attractive caves in the region. Organized caving and scientific and research activities are bringing tourists from a very specific niche - they are educated with environmental awareness, but they still should be observed and informed about possible risks for environment a s much as risks for themselves.

Organization of the speleo-tourist accommodation should be done out of caves in secured locations with mobile equipment for sewage and solid waste transport to safe places or existing settlements with appropriate waste management. Surroundings of caves are not suitable for any disposal of waste as it is usually advised 
to visitors in nature (digging of holes in soil for organic waste etc). The most attractive locations should be selected for placing permanent research camps with all necessary facilities (such as for instance in vicinity of Ledenica cave), electric supply and sanitary equipment. These facilities could be mobile, but this solution might not be a lever idea for majority of caves which are not available through existing road network. This does not mean that infrastructure should be immediately planned, but local transport could be organized through engagement of professional transporters (4-wheel drives, trucks) or farmers with horses, for instance.

To provide appropriate supply of water, organization of camping could include building of traditional stone tanks on the permanent camping sites or use of existing in remote villages and pastoral settlements, especially in those which are abandoned. Good arrangements with local population can provide perfect conditions for supplying visitors and cut pollution caused by increased need for intensive communication with markets in settlements. To make all concrete solutions suitable to the goal of protecting environment, it will be necessary to make detailed business plan, including environmental impact assessment.

Activities in the nature (land surface) Tracking, horseback and bicycle riding is part of geo as much as nature, nature protected areas and adventure tourism are basically not invasive themselves to the environment in areas such as karst mountain, where surface of tracks is mainly hard and rocky, yet tracks need to be planned carefully to avoid soil erosion on slopes and destruction of vegetation. Projecting MTB tracks is especially demanding. In general pollution within these activities can be caused in the same way as the one associated with caving. So, the same precautions are needed. Collection of garbage as much as fire protection and emergency reactions should be organized in cooperation with local community. Mountain rescue service should be extended with the alarming system on the field to react, yet precautionary measures including warnings in advance, warnings by signage and system of penalties must be predefined and available to visitors as much as their hosts. Tracks must avoid main breeding areas.

Hunting tourism should be limited to designated areas and regularly rotated to avoid long term pressure on certain habitats and populations. Control over disturbance by dogs and shooting, as much as control of poaching is a goal, and not just for the sake of conserving animal populations themselves, but also to provide economic benefits in long run. Introduction of atavistic hunting (bow hunting for instance) might be interesting for some species and territories which are easy to control. Introduction of blood tracking dogs is obligatory to prevent loses of wounded animals. It is crucial also to introduce arms check and reticulation, as much as checking skills of tourist-hunter before hunting to prevent miss in shooting and wounding of animals as much as possible. The pricelist should be changed to introduce full payment for wounded game instead of half price.

Photo-safari, and in particular bird watching should be environmentally safe activity, yet professional guiding and organization of these activities is required starting with the transport and designation of vehiclefree zones, towards type of stands and equipment selection. The safest approach to the transport in nature for hunting or watching of animals would be based on horse carriage and horseback-riding plus silent electric boats on waters, while stand should be carefully integrated in environment and made of natural materials to provide as less as possible impact on nature. Definition of the detailed plan of management of the area with unique features according to Ramsar convention will define more precisely all requirements. What is certain is that even bird watching should be limited in the areas of Veliki Ždralovac, which is a nucleus of protected landscape (reserved for scientific activities).

It is also crucial to come with consensus with foresters to permanently adjust their management practices, and exploitation of woods with hunting grounds management following Sustainable Forest Management principles. Introduction of feeding points might help revival of populations of birds of prey as much as prevent too heavy pressure on wild game. Hunting of wolfs and other predators is very attractive on the European market being forbidden in majority of countries due to their small populations or complete extinction. Canton $\mathrm{X}$ has no problem with protecting wolf, but with declining in pastoral traditions and extensive livestock husbandry the pressure on ungulates and wild pigs is increasing, which can cause problems of overpopulation (African fever is arriving from East to increase pressure).

Planned activities which include activities of tourists (and those within the tourism value chains supply) such as collection of wild plant and mushrooms, as much as a forest therapy should be permanently controlled. It is not expected that any of these activities should have any negative influence of environment. However, with increasing number of tourists, agriculture production will also increase, and livestock farming will tend to grow. 
The rehabilitation should go towards introduction of organic agriculture and reintroduction of low input animal husbandry to protect fragile karst environment from pollution.

With increasing number of tourists looking for accommodation in agro-tourism will emphasize the need for solving problems of sewage and waste in rural settlements as much as provision of renewable energy sources to prevent devastation of forests and decrease of the air quality. Present settlements with existing sewage management solutions cannot hold any increase of number of tourists without serious negative impact on environment.

Increase of the agriculture activities for production of additional food required by development of tourists is not going to happen soon, since now surplus of some agriculture products have first to be consumed, yet sooner or later initiative to increase production might bring an idea of intensification back on the top causing problems to environment. On the other hand, if proper farming systems are selected to support high nature value concept landscapes of Canton X might become even more attractive and local gastronomy get more attention. Development of rural tourism will bring problem with maintaining grasslands in forest zones also on the top of priorities. Namely, grasslands which are not managed tend to enter natural succession. The process has started by invasion of shrubby vegetation. Maintaining attraction for semi-natural vegetation, as much as diversity of landscapes is necessary to provide development of rural or any other kind of tourism. This imperative will help rehabilitation of the cultural landscapes of the area.

Proposed tourism products do not demand development of additional road infrastructure, so it has no potential impact on environment considering fragmentation of habitats and pollution as already mentioned. However, indirectly, development of rural tourism in the area will have an impact on the environment through potentially increasing traffic on existing roads. Increase will be provided also with increased need for mobility of people and goods within the region, which might not become an immediate problem, but it will be gradually increased. The environmental threats may occur also on the side of ineffective tourist management at most attractive natural resources. Other risks with possible impact on rural tourism are safety in traffic, undiscovered land mines from the war period 1992-1995 natural risks - natural disasters and weather (especially winter), and wild animals (snakes and mammal predators). Building adequate wildlife wardens/rangers service might be foreseen for developments align with destination management system establishment.

\section{CONCLUSIONS}

The main conclusions were conceived to promote rural tourism as a perspective way for supporting rural development of Canton X and confirm that rural tourism has potentials as a value adding instrument and market for local products. The seriousness of gaps in the heritage conservation must be filled, institutional support and networking of local stakeholders strengthened to provide favorable frame for strengthening and shorteing local value chains.

1. Canton $\mathrm{X}$ has very suitable geostrategic position. Being on the historical road between the Pannonian lowland and the Adriatic Sea (today's transversal linking EU Corridor 10 and the Mediterranean Highway), it is promising a good connection with emitting markets, yet lack of the modern highway might slow down tourism development.

2. Presently, tourism is a relevant source of income for very small number of rural households in Canton X. Despite opportunities which derive from introduction of rural tourism, rural households hesitate to diversify their economies due to insufficient labor force and skills, insufficient demand and poor market access, excessive financial risk, insufficient own capital, and expensive loans, while other sources of financial support still appear just occasionally.

3. Positive attitude of the population towards tourism and tourists, their openness and natural hospitality ensuring strong positive emotion that the guests experience during their stay is a promising asset for rural tourism development.

4. Canton X educates adequate high school profiles; yet, employment opportunities for local tourist, gastronomy and food production graduates are very limited. 
5. Tourism in the region has a deficit of professionals with new tourism occupations which require higher education. Exhaustive outmigration, which is a consequence of the scarce employment opportunities, continuously degrades human resources. This might slow down further development of tourism and prevent introduction of new tourist products.

6. Rural tourism seems to be the quality option for diversification of income and employment opportunities 'creation since high quality supply chains for food and beverages and activities in rural environment on demand on the modern tourist market exists (although with limitations) in Canton X. Rural tourism might be an efficient buster for revitalization and further development of both primary and secondary sectors which can in return provide supply through short value chains.

7. Tourism might provide better valorization of local food in Canton X. Rural tourism is a perspective way for supporting creation of the innovative short value chains which can play role of adding value instrument and market for local products (shortening value chains for local agriculture, forest non-wood and artisan food products) so it's suitable for interweaving in fragile Canton X rural economy.

8. Both eco-tourism and tourism of special interests, which include fishing and hunting, birds-watching, photo-safari etc. are possible due to availability of rich biodiversity resources. Existing infrastructure in hunting grounds represents a good base for hunting tourism development. Flora and fauna also have potentials to support diverse other activities, including edutainment and school tourism, short holidays, and family tourism as much as scientific/research tourism etc.

9. Territory of Canton X contains numerous natural and cultural tourist attractors over relatively small distances. Majority of these are not used for tourism and exposed to degradation. The main attractors for rural tourism of the region will remain its natural and cultural heritage. Therefore, rural tourism must be complemented with the offer of activities which are upgrading traditional experience towards adventure and wellness experiences.

10. Environmental risks are numerous and complex due to the specific nature of the area (karst), but also its recent history (remaining of the civil war), so the mitigation of these risk should precede every development action. The authentic local products can enrich the offer through gastronomy, but also events and animation. Their rehabilitation is of importance also for maintaining diversity and originality of landscapes. Rural tourism is a perspective way for supporting creation of the innovative short supply chains forest non-wood and artisan food products) so it's suitable for interweaving with fragile Canton $\mathrm{X}$ rural economy as a tool for promoting both primary and secondary industries with mutual benefit.

\section{ACKNOWLEDGMENT}

The paper represents the results of research within the FAO Project GCP/BIH/008/HUN.

\section{REFERENCES}

Bosnia and Herzegovina (2008). Law on Agriculture, Food and Rural Development of Bosnia and Herzegovina, Official Gazette of Bosnia and Herzegovina, No. 50/2008

Đorđević-Milošević S. \& Milovanović J. (2012). Održivi turizam u funkciji ruralnog razvoja - Mala poljoprivredna gazdinstva i ruralni turizam u Srbiji, Fakultet za primenjenu ekologiju Futura Beograd, Agroznanje Vršac, FAO Budimpešta

Đorđević-Milošević S. (2020). Rural Economies Diversification Prospects with Focus on Rural Tourism. In South-East Europe (Regional Synthesis) in Economic Diversification Policies and Rural Tourism in South East Europe (pp. 327-369), SWG RRD \& GIZ, N.Macedonia, Skopje, Retrieved September 15 ${ }^{\text {th }}, 2020$ from http://seerural.org/wp-content/uploads/2020/10/Rural-tourism-study.pdf

Đorđević-Milošević S., Milovanović J. (2020). Alternative Livelihoods Framework: Beyond the Risks and Stress Relief, In: Leal Filho W., Azul A., Brandli L., Özuyar P., Wall T. (eds), Zero Hunger. Encyclopedia of the UN Sustainable Development Goals, Springer, Cham

Đorđević-Milošević, S., Milovanović, J. (2014). Linking Rural Livelihood Diversity and Sustainable Development. Faculty of Applied Ecology Futura Singidunum University Belgrade. 193 pp. ISBN 978-86-86859-35-8 
Fayos-Solà, E., Fuentes Moraleda, L. and Isabel Muñoz Mazón, A. (2014). “The FAS Model”, Tourism as an Instrument for Development: A Theoretical and Practical Study (Bridging Tourism Theory and Practice, Vol. 5), Emerald Group Publishing Limited, pp. 55-86. Retrieved August $15^{\text {th }}, 2020$ from https://doi.org/10.1108/S2042-144320140000006012

Federalno ministarstvo okoliša i turizma (2009). Master plan razvoja turizma za područje Kupresa, Retrieved September $30^{\text {th }}, 2020$ from https://www.opcinakupres.ba/dokumenti/doc_download/181-master-planrazvoja-turizma-za-podrucje-kupresa

Federation of Bosnia and Herzegovina (2009a). Law on Tourist Activities, Official Gazette Federation of Bosnia and Herzegovina, No. 32/2009

Federation of Bosnia and Herzegovina (2009b). Law on Catering, Official Gazette Federation of Bosnia and Herzegovina, No. 32/2009

Federation of Bosnia and Herzegovina (2011). Tourism Strategy for Federation of Bosnia and Herzegovina 2011-2020, Retrieved September $15^{\text {th }}, 2020$ from https://www.fmoit.gov.ba/bs/turizam

Food and Agriculture Organization of the United Nations (2008). Promotion of traditional regional agricultural and food products: a further step towards sustainable rural development, $26^{\text {th }} \mathrm{FAO}$ Regional conference for Europe report ERC/08/REP, Innsbruck, Retrieved September 15 ${ }^{\text {th }}, 2020$ from http://www.fao.org/ tempref/docrep/fao/meeting/014/k3400E.pdf

Keane M. (2000) Rural Tourism and Rural Development. In: Briassoulis H., van der Straaten J. (eds) Tourism and the Environment. Environment \& Assessment, vol 6. Springer, Dordrecht, Retrieved September 15 ${ }^{\text {th }}$, 2020 from https://doi.org/10.1007/978-94-015-9584-1_6

Kodžo S., Kutić A., Kodžo D. (2015). Zaštita prirode i kraškog okoliša na području Livanjskog polja kao predmet prostorne analize i strateškog planiranja, Naš krš, XXXV, 48, Sarajevo, pp.50-62, Retrieved August $15^{\text {th }}$, 2020 from https://doi.org/10.1007/978-94-015-9584-1_6

Lugonja A. (2013): Geographical basis of tourism development of territory the Kupres, Researches Review DGTH | 43-2, pp. 118-129, UDC 338.486(497.5) Retrieved August 15 ${ }^{\text {th }}, 2020$ from http://www.dgt.uns. ac.rs/dokumentacija/zbornik/43-2/en/03.pdf

Ministarstvo okoliša i turizma Federation of Bosnia and Herzegovina (2008). Strategija razvoja turizma za period 2008-2018

Ministry of Foreign Trade and Economic Relations (2018). Strategic plan for rural development of Bosnia and Herzegovina (2018-2021) - framework document, Ministry of Foreign Affairs and Economic Relations, Sarajevo

Ničić M. (2015).Turizam zasnovan na baštini: ideološki procesi i implikacije, SITCON 2015 - Singidunum International Tourism Conference, DOI: 10.15308/sitcon-2015-242-247

Nurkovic R., Dzeko S. (2014). Rural Tourism as a Factor of Development of Economic Activities in Rural Areas of Bosnia, Rural tourism as a factor of development of economic activities in rural areas of Bosnia and Herzegovina. International Geographical Union (IGU) Regional Conference, 18-22 August 2014, Kraków, Poland

Šiljeg A., Šiljeg S., Šiljković Ž. (2010). Stanje i tendencije razvoja turističke ponude općine Kupres (Bosnia and Herzegovina), Geoadria 15/2

Sivrić I. (2020). Economic Diversification Policies \& Institutions Supporting Rural Tourism in Bosnia and Herzegovina. in Economic Diversification Policies and Rural Tourism in South East Europe, p.p 71-120, SWG RRD \& GIZ, N. Macedonia, Skopje, Retrieved September 15 ${ }^{\text {th }}, 2020$ from http://seerural.org/wpcontent/uploads/2020/10/Rural-tourism-study.pdf

Stagl, S. (2006). Rural Tourism and Resilience of Regions. Part of WP 2 - Learning for Social-Ecological Resilience and Diffusion of Innovations. Working Paper prepared within the IDARI Project WP 2

Udovč, A. i Perpar, A. (2007) Role of rural tourism for development of rural areas. Journal of Central European Agriculture, 8 (2), p.p 223-228, Retrieved September 15 ${ }^{\text {th }}, 2020$ from https://hrcak.srce.hr/17909

United Nations Development Programme (2018). Tourism and the Sustainable Development Goals - Journey to 2030, file://C:/Users/Suzana/Downloads/UNWTO_UNDP_Tourism\%20and\%20the\%20SDGs.pdf

United Nations Economic Commission for Europe (2018). Environmental Performance Reviews Bosnia And Herzegovina, Environmental Performance Reviews Series No. 48, Retrieved September 30 ${ }^{\text {th }}, 2020$ from https://www.unece.org/fileadmin/DAM/env/epr/epr_studies/ECE.CEP.184.Eng.pdf

Vlada Herceg-Bosanske Županije (2016) Strategija razvoja Herceg-Bosanske Županije za razdoblje 2016-2020, Retrieved September 15 ${ }^{\text {th }}, 2020$ from http://www.vladahbz.com/sadrzaj/dokumenti/strategija-razvoja/ strategija\%202016.pdf

Vlada Herceg-Bosanske Županije (2018) Draft Strategy for Agriculture and Rural Development in Canton X, 2018-2024, unpublished document developed by the FAO Project GCP/BIH/008/HUN 